\title{
An Assessment of Acoustic Quality in Mosque Case Study: Masjid At-Tarbiyah UIN Malang
}

\author{
Aisyah Nur Handryant ${ }^{1, *}$ \\ ${ }^{I}$ Department of Architecture, Faculty of Science and Technology, UIN Maulana Malik Ibrahim Malang, Indonesia \\ *Corresponding author.Email: aisyahhandryant@arch.uin-malang.ac.id
}

\begin{abstract}
Acoustic quality is an essential aspect in the design of spaces, including mosques. A mosque as a worship place has several activities that require good acoustic quality, especially in terms of delivering a clear sound. Masjid At-Tarbiyah is one of the mosques on the UIN Malang campus. This research was conducted to determine the value of acoustic quality in the Masjid At-Tarbiyah and analyze the factors that influence it. This research is a quantitative research that looks at the value of room acoustics' quality with modeling and simulation of the Ecotect v.2011 program. The acoustic quality value is calculated based on the reverberation time value known from the simulation-based on observations and physical measurements of space in the field. The RT value reaches 7.86 seconds at a frequency of $500 \mathrm{kHz}$, and the average RT is 3.467 seconds. This study indicates that the value of acoustic in Masjid At-Tarbiyah is low, as indicated by the high RT, so that space improvement is needed.
\end{abstract}

Keywords: Acoustic, Mosque, Reverberation Time

\section{INTRODUCTION}

Space acoustics are defined as forms and materials in a room related to changes in sound. Acoustics means a symptom of sound change due to the nature of the reflection of objects or passive objects from nature. Room acoustics are very influential in sound reproduction and will significantly affect the speaker's articulation and clarity. Space acoustics are associated with two fundamental things, namely sound changes due to reflection and sound disturbance through sound from other rooms. [1]

Acoustic quality is an essential aspect in the design of spaces, including mosques. The mosque is a place for Muslim worship and also be a community development center. Due to its primary function as a place of worship, a mosque is subjugating a noble place in Islam [2]-[3]. A mosque as a worship place with several activities needs good acoustic quality, especially in delivering a clear sound. [2]-[4] Some mosque activities that require good acoustic quality include congregational prayers, religious lectures, to recitation activities. [5] Failure or low acoustic quality in a mosque can seriously interfere with the mosque's main activities, for example, unclear voices during religious lectures and discomfort during congregational prayers. [6]
General criteria for mosque acoustics are sufficient sound hardness, even sound distribution, optimum reverberation time, which affects clear speech, free from acoustic defects, and low noise levels. Indoor loudness is measured by the Sound Pressure Level in the decibel scale (dB). The SPL value shows the listener's sound's strength or loudness at a point in space with a certain distance from the sound source. If the sound emitted from the sound source can be captured with the same loudness by the listener at all positions or points in the room, then it is said that the distribution of the sound in the space is even. The level of hum in space is measured by Reverberation Time in seconds. [7]-[8]

Research about acoustic in the mosque is few. Some researcher who studies about mosque acoustic in general are (1) Setiyowati [9] in his research The Effect of Mosque Architecture in Tropical Areas on the Acoustic Quality of Space made observations in several mosques with a focus on aspects of plans, ceilings and openings, (2) Adel A. Abdou [10] on 'Comparison of The Acoustical Performance of Mosque Geometry Using Computer Model Studies,' (3) Icha, et al. [11] with the title' Study on the Effect of Ceiling Shape to the Acoustics Condition of Mosque using Computer Simulation,' and (4) Abdullah et al. [12] on 'A Study of the Acoustics and Speech Intelligibility Quality of Mosques in Malaysia.' These studies examine the aspects 
that affect mosques' acoustic quality by comparing and simulations of various models and materials in mosques. Other research on mosque acoustics is about measuring certain mosques' acoustic quality done by Nazli et al. [13] and Kassim et al. [14].

This research conduct in a mosque in UIN Maulana Malik Ibrahim Malang. UIN Maulana Malik Ibrahim Malang is one of the largest Islamic universities in Malang. This university implements Islamic integration, which is manifested in the pillars of higher education includes mosques. UIN Malang has mosques spread in building campuses, and it has an essential role in the campus. There are many student activities in the mosque, such as congregational prayer activities, recitation activities, and studying Al-Qur'an activities. The mosque at UIN Malang is also the basis of worship for the academic community. It is marked by the routine scientific discourse activities of every Dhuhur prayer, whose speakers are lecturers and academic staff of UIN Malang. Research about acoustics in mosques of UIN Malang has never been done by other researchers before.

One of the issues faced by mosques at UIN Malang is many sources of noise from the surround. This noise usually disturbs the quality of the mosque's acoustics. This study aims to determine the value of acoustic quality in the Masjid At-Tarbiyah and analyze the factors that influence it. The aspects that will focus on this study are aspects of the mosque building's shape and the physical elements of the space.

\section{METHOD}

This research is a quantitative study that looks at the value of space acoustics' quality in campus mosques at UIN Maulana Malik Ibrahim Malang. This study analyzes the factors that influence the value of space's acoustic quality and looks for strategies to improve acoustic quality. This study uses modeling and simulation using the Ecotect v.2011 program to determine the value of acoustic quality in the research object to calculate the reverberation time (RT). RT is used to measure room acoustics' quality based on reverberation time standards [15] for the talking room, which will affect all interior elements of the space, such as walls, ceilings, and openings.

\section{RESULT AND DISCUSSION}

\subsection{Physical Condition of Space}

Masjid at-Tarbiyah is the main mosque on UIN Malang campus. This mosque has a primary function as a place of worship for the academic community of UIN Maulana Malik Ibrahim Malang. Some of the activities carried out in this mosque include congregational prayers five times a day, ta'lim (religious studies) activities, student and lecturer discussion activities, and several ma'had (boarding house) activities. Masjid At-Tarbiyah has initially been used as a worship place for the student who lived in the ma'had or boarding house for one year in the first year. However, this mosque is now devoted only to male student activities and other academic activities during working hours.

This mosque is located in the northern part of the campus complex [Fig. 1]. The mosque's western boundary is the ma'had building, the east is the el-zawa building, the northern boundary is the dividing wall and the neighborhood road, the south border is the campus road. This condition makes the mosque get noise from the activities and vehicles of campus residents.

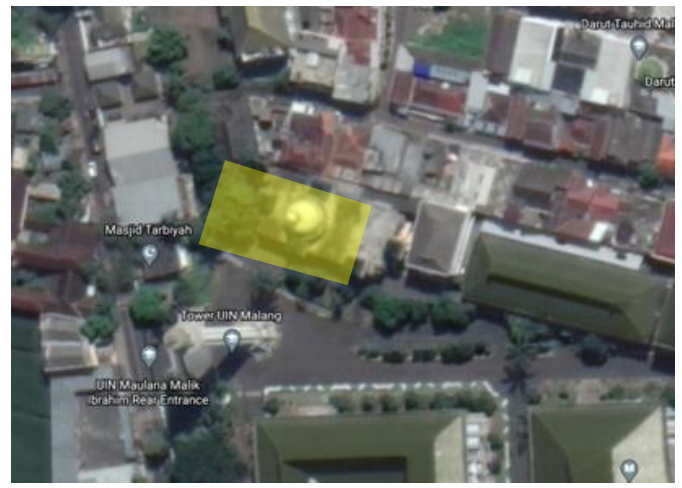

Figure 1 Siteplan Masjid Tarbiyah Source: GoogleEarth, 2020

This mosque's architectural style is an ArabicIndonesian eclectic style shown by the combination of the domed and the joglo roof. This mosque consists of two floors with a natural interior atmosphere in brown and beige. This mosque plan is rectangular, and the roof is a combination of a dome shape and a joglo or Javanese roof supported by a flat concrete roof. This mosque's overall dimensions are $33 \times 19 \times 7 \mathrm{~m} 3$, and the main prayer room dimensions are $25 \times 17 \times 7 \mathrm{~m} 3$.

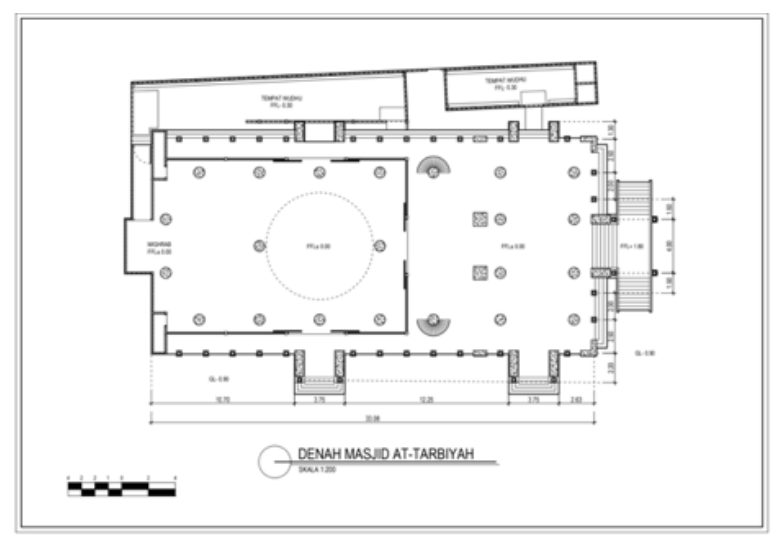

Figure 2 Floor plan of the Masjid At-Tarbiyah 


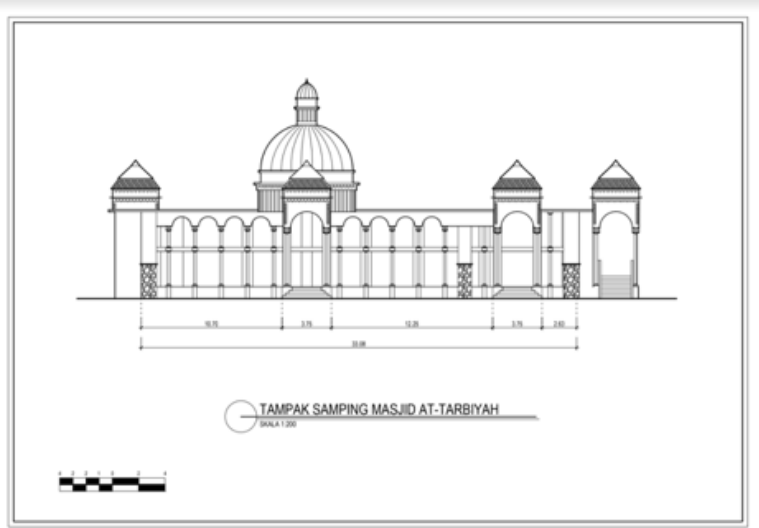

Figure 3. Elevation of Masjid At-Tarbiyah

Tabel 1. Materials in interior of Masjid At-Tarbiyah

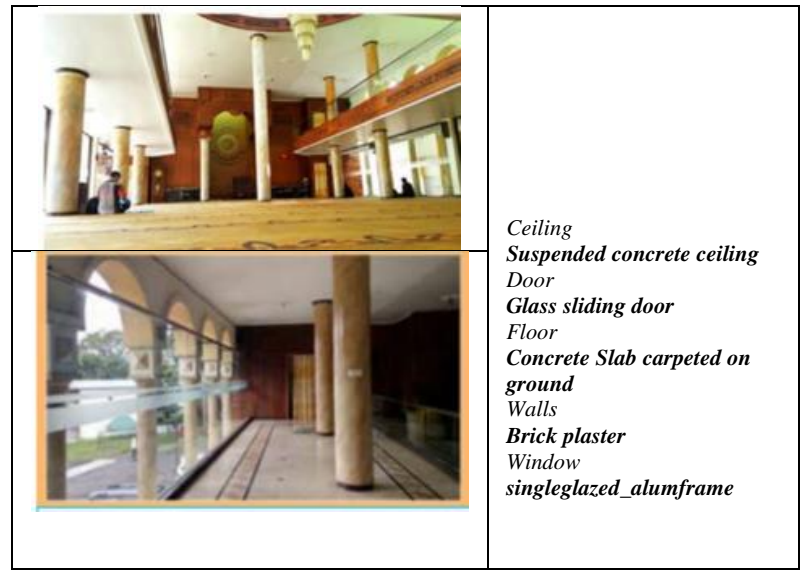

The main prayer room has a rectangular shape dominated by cement plaster walls with paint finishing, large single glass windows, carpeted floors, and a flat and dome-shaped concrete roof. The form of the joglo roof is only found in the entrance zone with the ceiling. The composition of the material is classified as material that has a large reflective power such as large glass windows, painted brick walls, marble floors, and glass doors. The absorbent material in the form of a carpet is only about $1 / 3$ of the entire floor, namely on the 1 st floor of the main prayer room.

Preliminary research has been conducted to determine the condition of acoustic quality through direct observation. Observations were made during religious lectures and it was known that there was a faint sound in the room. Unclear conditions or sounds that do not reach the listener's ears occur mainly in the rearmost area and the second-floor area. Besides, there is also an acoustic defect in the form of an echo at these points.

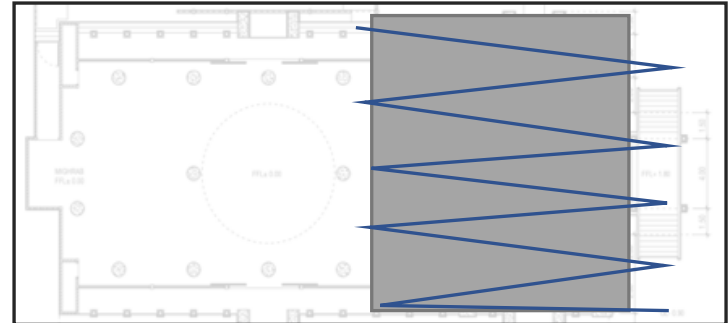

Figure 4. Area of unclear sound

\subsection{Spatial Physical Modeling}

Before the simulation, modeling was carried out by simplifying a working drawing made from the Masjid AtTarbiyah Masjid At-Tarbiyah in the Ecotect 2011 software. Modeling was only carried out in the main prayer room due to the limitations of the research.

Figure 5 shows the plan of Masjid At-Tarbiyah in a rectangular shape with a building height of two floors. Figure 6 shows the perspective of the Masjid At-Tarbiyah with a dome and flat roof.

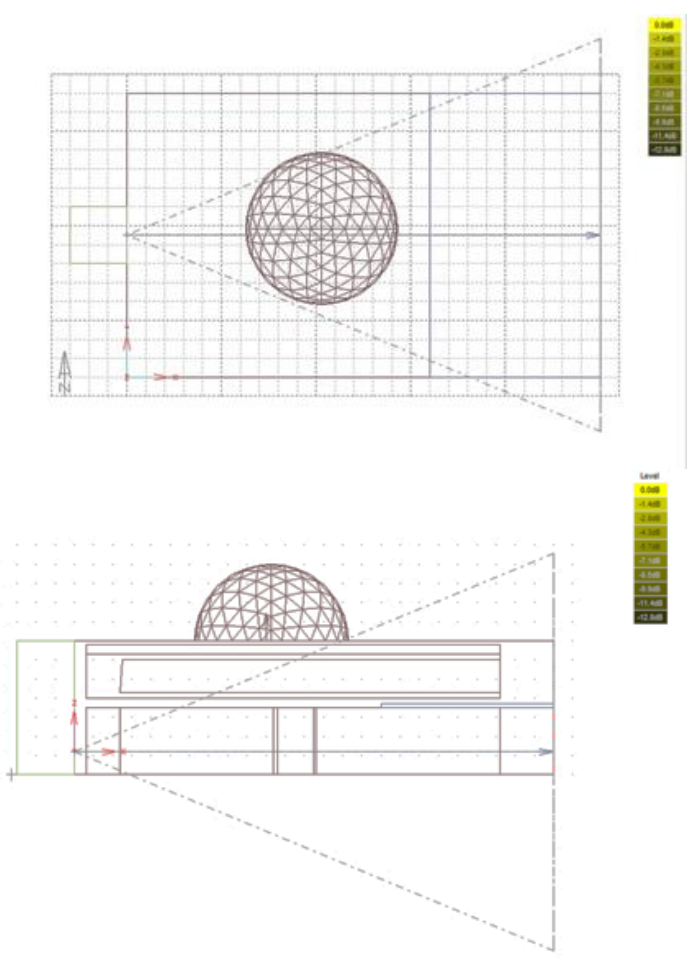

Figure 5 Floor Plan and Elevation Model of Masjid AtTarbiyah (Ecotect v.2011) 


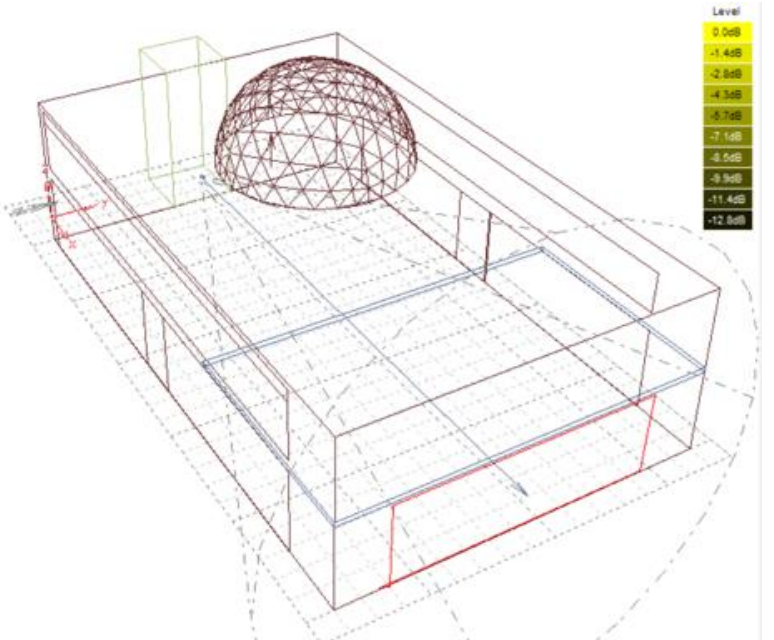

Figure 6. Perspective Model of Masjid At-Tarbiyah (Ecotect v.2011)

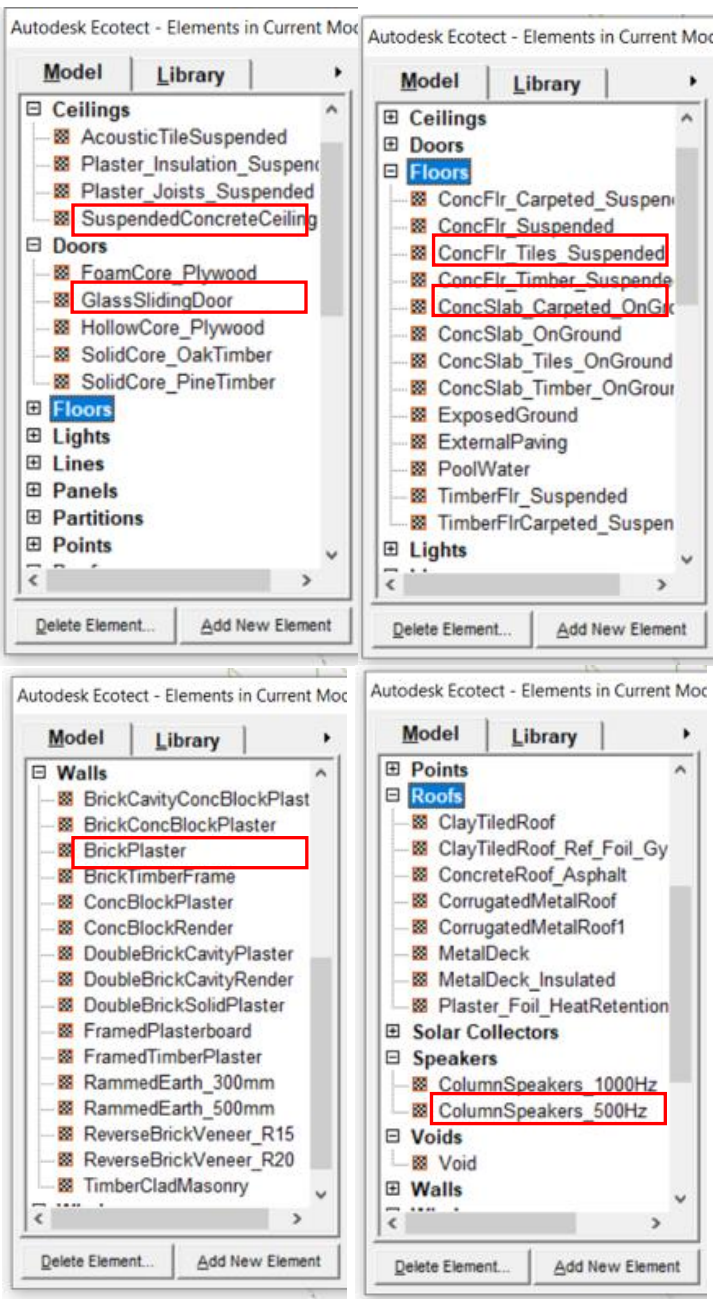

Figure 7. Materials list in material library Ecotect v.2011
The material used in the model is taken from the material library in Ecotect_v.2011. Figure 7 shows the selected material according to the original material or closer to the original material.

The material used in the Masjid At-Tarbiyah model is the same and approaches the material in the field. Part of this material is in the Ecotect v.2011 material library. Materials that are not in the material library are adjusted by selecting an absorption coefficient close to the material in the field.

\subsection{Acoustic Simulation Results}

Tabel 2. Masjid At-Tarbiyah RT value

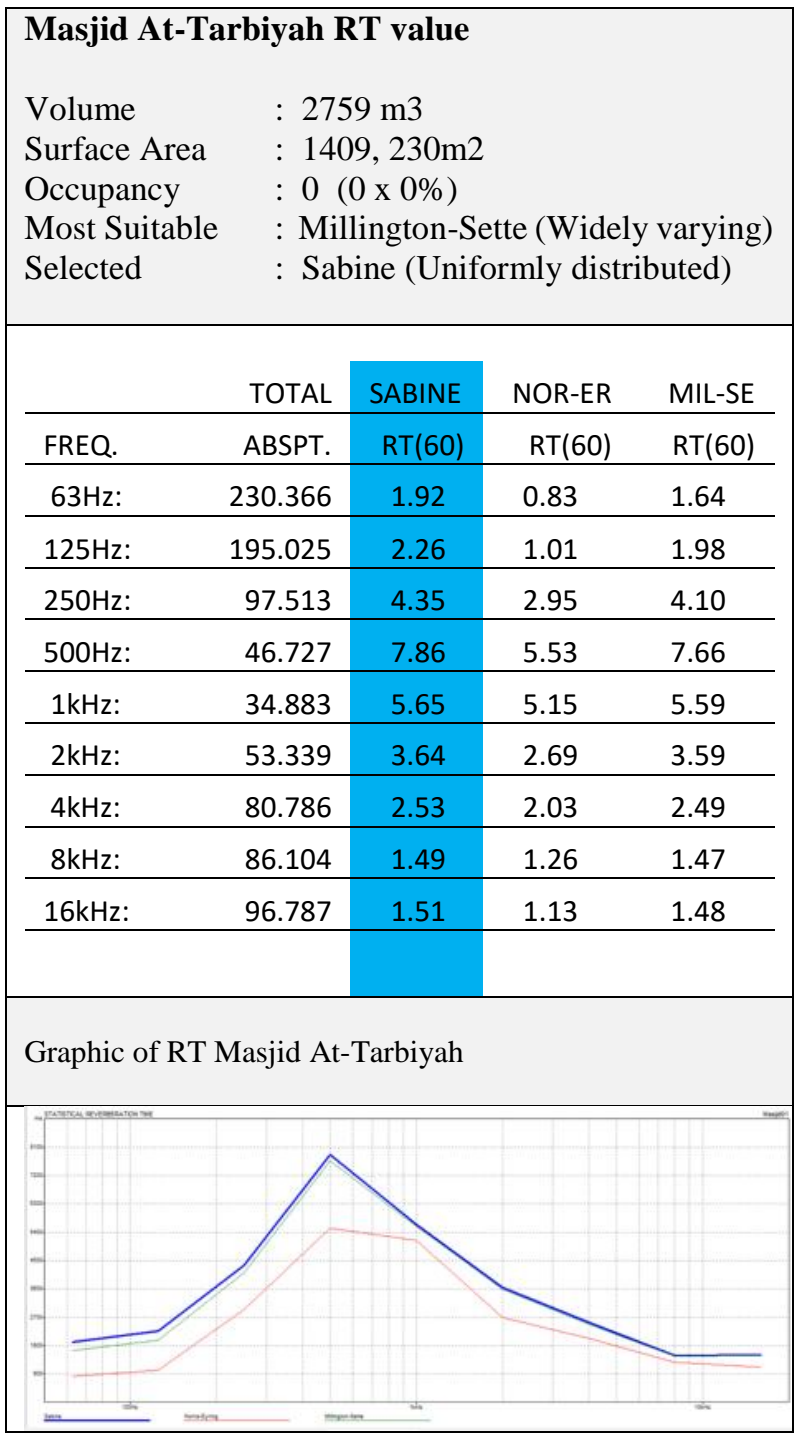

The next step after modeling is the reverberation time (RT) simulation. The simulation is carried out by entering all the selected materials into the model. After entering all the materials according to the existing conditions, the mosque's RT value calculation is 
obtained. In the Ecotect v.2011 program, three RT values are generated. In this study, the RT value taken by RT Sabine was because it was more common and suitable for use. Table 2 describe the RT value in Masjid AtTarbiyah.

Based on the RT table and graph above, it is known that the RT value in the Masjid At-Tarbiyah is high. The high level is based on the standard RT value for religious buildings, especially the ideal mosque, between 0.9 and 1.2 seconds. The highest RT value is at the $500 \mathrm{~Hz}$ frequency, which is 7.86. The dominant reflective area is influences the RT's value in the Masjid At-Tarbiyah, which is a glass window with the size of a wall and a concrete ceiling. Figure 8 shows the sound movement at Masjid At-Tarbiyah. The sound is reflected evenly throughout the room after released. The main areas of reflection at the Masjid At-Tarbiyah are glass walls and a concrete ceiling.

Based on the picture above, it is known that after the sound comes out of the sound source or speakers from the mihrab area, the sound then spreads out into three main areas, that are the ceiling, walls, and carpet floors. Figure 9 shows the direction of the sound reflection. The sound hitting the carpet floor is absorbed and only reflected in a small amount. On the other hand, the sound hitting the glass-windowed walls and ceiling is still reflected in the prayer room's back area and the mezzanine area.
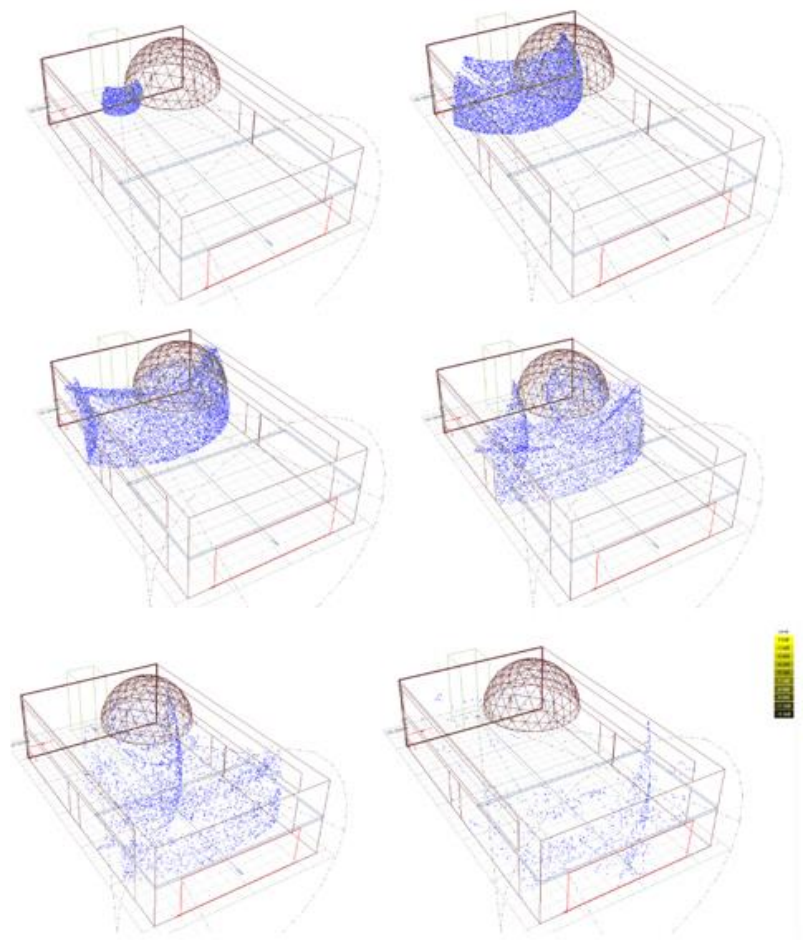

Figure 8 Sound movement in Masjid At-Tarbiyah

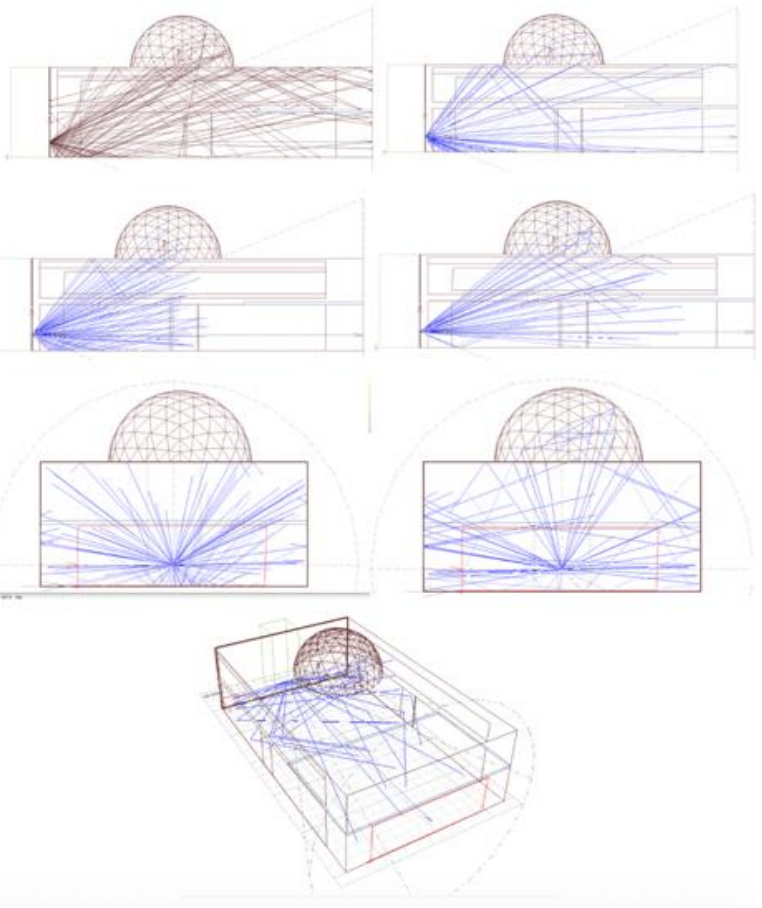

Figure 9 Direction of Sound Reflection at Masjid At-Tarbiyah

Based on the simulation results of acoustic quality at Masjid At-Tarbiyah, it is known that the acoustic quality is low, which is indicated by the high RT value. The highest reaching 7.86 seconds at a frequency of $500 \mathrm{kHz}$ as well. The average value of RT in Masjid AtTarbiyah is 3.467 seconds.

The high value of the RT was caused by the extent of the reflected material in the mosque. These reflective materials include glass materials that tend to be closed, plaster brick wall materials, and ceiling materials made of reinforced concrete and gypsum. Besides, the shape of the dome mosque roof also contributes to reflected sounds in the mosque [15].

Based on the simulation results of acoustic quality at Masjid At-Tarbiyah, it is known that the acoustic quality is low. This is indicated by the high RT value, the highest reaching 7.86 seconds at a frequency of $500 \mathrm{kHz}$ as well. The average value of RT in Masjid At-Tarbiyah is 3.467 seconds and 5.514 seconds at Ulul Albab Mosque.

The high value of the RT was caused by the extent of the reflected material in the two mosques. These reflective materials include glass materials that tend to be closed, plaster brick wall materials, and ceiling materials made of reinforced concrete and gypsum. Besides, the shape of the dome mosque roof also contributes to reflected sounds in the mosque. 


\section{CONCLUSION}

Based on the simulation and RT calculations, it is evident that there is an acoustic defect in the Masjid AtTarbiyah in line with preliminary research. The acoustic issues that occur at the Masjid At-Tarbiyah are uncontrolled sound reflection, sound delayed and echoes. The issues proved by modeling and simulation results that RT in masjid At-Tarbiyah is high. The highest RT is at the $500 \mathrm{~Hz}$ frequency, which is 7.86 seconds. The average value of the RT in Masjid At-Tarbiyah is 3.467 seconds. The dominant reflective area is influences the RT's value in the Masjid At-Tarbiyah, which is a glass window with the size of a wall and a concrete ceiling.

This research concludes that the acoustic value in Masjid Tarbiyah is low and the strategies to improve the quality of audial comfort are needed. Meanwhile, the strategy carried out is only limited to adding acoustic elements such as absorbent areas in mosque elements (walls, floors, ceilings and roofs) because it is impossible to change the mosque's physical building completely. Strategies that can be done include the following:

1. Adding an opening in the wall area that has an extensive reflective material.

2. Replacing ceiling material with a material that has high sound absorption.

3. Adding furniture in areas is located too far from the sound source to direct the sound to the desired place.

\section{REFERENCES}

[1] E. Setiyowati, Strategies to Increase the Acoustical Quality of the Mosque without Reinforcement System, in: Journal of Islamic Architecture, vol. 1, no. $1,2010.2$ DOI: https://doi.org/10.188860/jia.v1i1.1714

[2] N.A. Adnan, R.F.R. Shahminan, F.K. Ibrahim, H. Tami, M.R.M. Yusuff, E.M. Samsudin, I. Ismail, Acoustic Quality Levels of Mosque in Batu Pahat, in: IOP Conference Serie: Earth and Environmental Science $140, \quad 2018.2$ DOI: https://doi.org/10.1088/1755-1315/140/1/012009

[3] A.R Al-Jaziri, Kitab Al-Fiqh Ala Al-Madhahib AlArba'ah, Beirut: Dar Al-Kutub Al- Ilmiyyah, 1986.

[4] A.O. Wasim, Sound parameters in mosques, in: Proceedings of Meetings on Acoustics, Vol. 1, 035001, Salt Lake, Utah, 1 - 21, 2007.

[5] A.R. Othman, C.M Harith, N. Ibrahim, S.S. Ahmad, The Importance of Acoustic Design in the Mosques towards the Worshipers' Comfort, Procedia - Social and Behavioral Sciences, vol. 234, pp. 45-54, 2016. DOI: https://doi.org/10.1016/j.sbspro.2016.10.218.
[6] A. Abdou, Measurement of Accoustical Characteristicsof Mosque in Saudi Arabia, in: The Journal of the Acoustical Society of America, 113

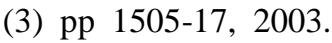

DOI: https://doi.org/10.1121/1.1531982

[7] N.U.I. Dewi, N. Rahmawati, Kualitas Akustik Ruang Utama Masjid Siti Aisyah Surakarta, in: Sinektika: Jurnal Arsitektur, 16. pp 73-79, 2020. DOI: https://doi.org/10.23917/sinektika.v16i2.10592.

[8] Soegijanto, Research on Acoustic Performance of Mosques in Indonesia: Report on Competitive Grants for Higher Education IX Bandung.

[9] E. Setiyowati, The Effect of Mosque Architecture in Tropical Areas on the Acoustic Quality of Space in Thesis Master Program, 2008.

[10] A. Abdou, Comparison of the Acoustical Performance of Mosque Geometry using Computer Model Studies, Eighth International IBPSA Conference, Eindhoven, Netherlands August 11-14, 2003.

[11] Icha, Venanda, Soegijanto, Triyogo, Study on the Effects of Ceiling Shape to the Acoustics Condition of Masjid by Means of Computer Simulation, The $6^{\text {th }}$ International Seminar on Sustainable Environmental and Architecture, Department of Architecture ITB, 2005.

[12] A.H. Abdullah, Z.A Zulkefli, A Study of the Acoustics and Speech Intelligibility Quality of Mosques in Malaysia, Applied Mechanics and Materials, 2014, 564. 129-134. DOI: https://doi.org/10.4028/www.scientific.net/AMM.5 64.129.

[13] N.B.C. Din, N.A.A Jalil, Y. Ahmad, R. Othman, Measurement of the acoustical performance of traditional vernacular mosques in Malaysia, The 43rd International Congress and Exposition on Noise Control Engineering (Inter-Noise 2011).

[14] H. Kassim, A. Putra, J.M. Nor, The acoustical characteristics of the Sayyidina Abu Bakar Mosque, in: UTeM Journal of Engineering Science and Technology, 10. 97-110, 2015.

[15] S.M.N. Imam, N. Ahmed, D. Takahashi, An Optimum Reverberation Time for Mosque in Bangladesh, in: the Bangladesh Journal of Scientific and Industrial Research, vol. 44 no. 2, 2009.

DOI: https://doi.org/10.3329/bjsir.v44i2.3667

[16] A. Elkhateeb, A. Adas, M. Attia, Y. Balila, Are Our Masjids Suffering Excessive Reverberation, in: The $23^{\text {rd }}$ International Congress on Sound and Vibration, Athens, Greece, 10-4 July 2016. 